\title{
A Review on Ethnobiological \& Medicinal Potential of Capparaceae Family Plant: Capparis decidua (Forssk.) Edgew
}

\author{
Prashant Kumar Dhakad ${ }^{1, *}$, Pramod Kumar Sharma ${ }^{1}$, Sokindra Kumar ${ }^{2}$ \\ ${ }^{1}$ Department of Pharmacy, Galgotias University, India \\ ${ }^{2}$ R.V. Northland Institute (RVNI), Chithera, Dadri, Greater Noida-II, India
}

Copyright $\bigcirc 2016$ by authors, all rights reserved. Authors agree that this article remains permanently open access under the terms of the Creative Commons Attribution License 4.0 International License

\begin{abstract}
Rajasthan state is rich in flora of xerophytic plants. Capparis decidua (Forssk.) Edgew. is a wild bushy plant found in hot arid regions. This plant has wide range of distribution in many parts of India. Ethnobiologically, this plant is useful as its various parts like immature flower buds, semi-mature fruits, young shoots with small leaves are pickled for use as a condiment and traditional people use this plant in treating ailments like digestive diseases, anodyne, sudorific, constipation, gout, cough, flu, dropsy, palsy, asthma, and intestinal worms, lumbago, odontalgia. Capparis decidua (Forssk.) Edgew. contains chemical compounds like alkaloids, flavanoids, terpenoids, phenolic compounds, steroids, vitamins, quarternary ammonium compounds and many more phytoconstituents that are responsible for its medicinal value. Different parts of this plant like seed, root, stem, flowers, fruits and leaves have medicinal importance and has shown numerous pharmacological activities like antimicrobial, antibacterial, antifungal, anti-inflammatory, antioxidant, hepatoprotective, anthelmintic, antidiabetic, antisebum, antihyperlipidemic, antisclerotic, antitermite, antiplaque, analgesic, sedative and anticonvulsant. Economic importance of this plant has tended for harvesting, yield and marketing specifically in Thar Desert. Future potential of this crop is very promising as it is a drought and heat tolerant plant which makes it a good weather forecasting species; also it provides people with food (pickle \& vegetable), fodder, wood and fuel. The presence of numerous phytoconstituents makes it a medicinally important crop for treating deadly diseases. This review covers taxonomy, distribution, phytochemicals, and nutritional value, and commercial value, traditional and pharmacological aspects of Capparis decidua (Forssk.) Edgew.
\end{abstract}

Keywords Capparis decidua (Forssk.) Edgew., Xerophytic, Phytoconstituents, Pharmacological Activities

\section{Introduction}

The wild plants have been utilized by native community in a medicinal way to cure cuts, wounds, burns and other disease ailments having dietary or pathogenic origin. Rajasthan state is having extremely dry climatic conditions and local community is coupled with poverty and natural disaster like drought which is challenging for them to cope up with food and medicine. But the flora of this state comprises of drought resistant plants having photochemical and mineral ingredients to carry out nearly all biological reactions of body. [1-4]. As per the reports, it is estimated that about $70-80 \%$ of world population, especially in developing countries, depends on plant medicine to prevent and cure diseases. In addition, it has been reported that about $25 \%$ of the synthesized drugs are being derived from medicinal plants $[4,5]$. Capparis decidua (Forssk.)Edgew.(Kair) is a multipurpose perennial woody plant, of caper family (Capparaceae), found chiefly in hot arid region of different parts of world. The caper family includes 650 species of plants found in 30 genera located principally in tropical and warm temperate regions. Nearly 26 of these species are reported to occur in India [6]. Because of its xerophytic adaptive nature this plants grows well under the harsh climatic conditions of arid regions. Capparis decidua (Forssk.) Edgew. is salt-tolerant and grows along saline hard planes in Thar Desert. Mature plants develop extensive root systems that penetrate deeply into the soil. Leaf stipules form into spines to reduce transpiration. It also protects birds and animals from scorching heat during summers. [7]

\subsection{Taxonomical Classification [8]}

Kingdom: Plantae

Division: Phanerogamae

Subdivision: Angiospermae

Class: Dicotyledonae 
Subclass: Polypetalae

Order: Thalamiflorae

Suborder: Parietales

Family: Capparaceae

Genus: Capparis

Species: deciduas

\subsection{Monograph}

Arabic: Hanbag, Kiabara, Margh, Sodab, Tundub

Deccan: Karyal

English: Caper berry, Caper bush, Caper plant

Hindi: Kabra, Kachra, Karer, Karil, Karu, Kurrel, Pinju,

Teent, Tent, Tenti

Sanskrit: Apatra, Chakrak, Granthil, Gudhpatra, Kantaki

Rajasthani: Kair, Kareal, Kerro, Taint

Scientific Name: Capparis deciduas

Family: Capparaceae

Duration: Perennial

Growth Habit: Grows abundantly in dry, arid and exposed habitat like wastelands, ditches, drying ponds, cultivated lands, road sides and surrounding plains of hills as it is tolerant to prolonged drought due to its excellent adaptation to arid conditions.

Nativity: Dry places in Sind, Baluchistan, Western Rajputana, Deccan Peninsula, Egypt, Socotra, Arabia, Tropical Africa, Central India, Punjab, Gujarat, Tinnevelly and Pakistan.

\section{Botanical Description}

Capparis decidua (Forssk.) Edgew.(Kair) is a spiny, much dense and slender branched, green twiggy looking shrub or small tree growing gregariously bearing dense spherical crowns. The stem bark is smooth, green when young and turns yellow or whitish grey as it matures [9]. Leaves are deciduous, glabrous, small caducous, succulent that appear for maximum of one month, on new shoots. New leaves sprout from January to November [10], being sessile with very short petioles, pointed and small (2-12 $\mathrm{mm}$ in length and $1-3 \mathrm{~mm}$ in width). Fruits are globose, borne on a long stalk, green when immature and red or pink when ripened. Ripe fruits contain a sweet yellow pulp with many seeds. Flowering occurs on young shoots of the current year. Narrow leaves and stipular spines on shoots help reduction in loss of water due to transpiration in extremely drought conditions. It has well developed tap root systems which uptake water within ground at a depth of up to $4 \mathrm{~m}[11]$.

\section{Distribution in Hot Arid Regions of India}

The natural habitat of Capparis decidua (Forssk.) Edgew. is on the lowerside of plains all over the hot and dry regions, semi- stabilized dune peripheries [12]. Capparis decidua (Forssk.) Edgew flourishes well on shallow hard soils and rocky outcrops but not on shifting sand dunes or water logged areas [13]. It grows abundantly in sandy, saline and gravy soils of $\mathrm{pH} 6.5-8.5$. It can tolerate temperatures as high as $50^{\circ} \mathrm{C}$ and as low as $0{ }^{\circ} \mathrm{C}$. It has also been found to thrive well on saline sodic soils [14]. This species shows wide genetic variability in plant size, morphology, fruit production and dimorphism in seeds. [15] (Figure 1)

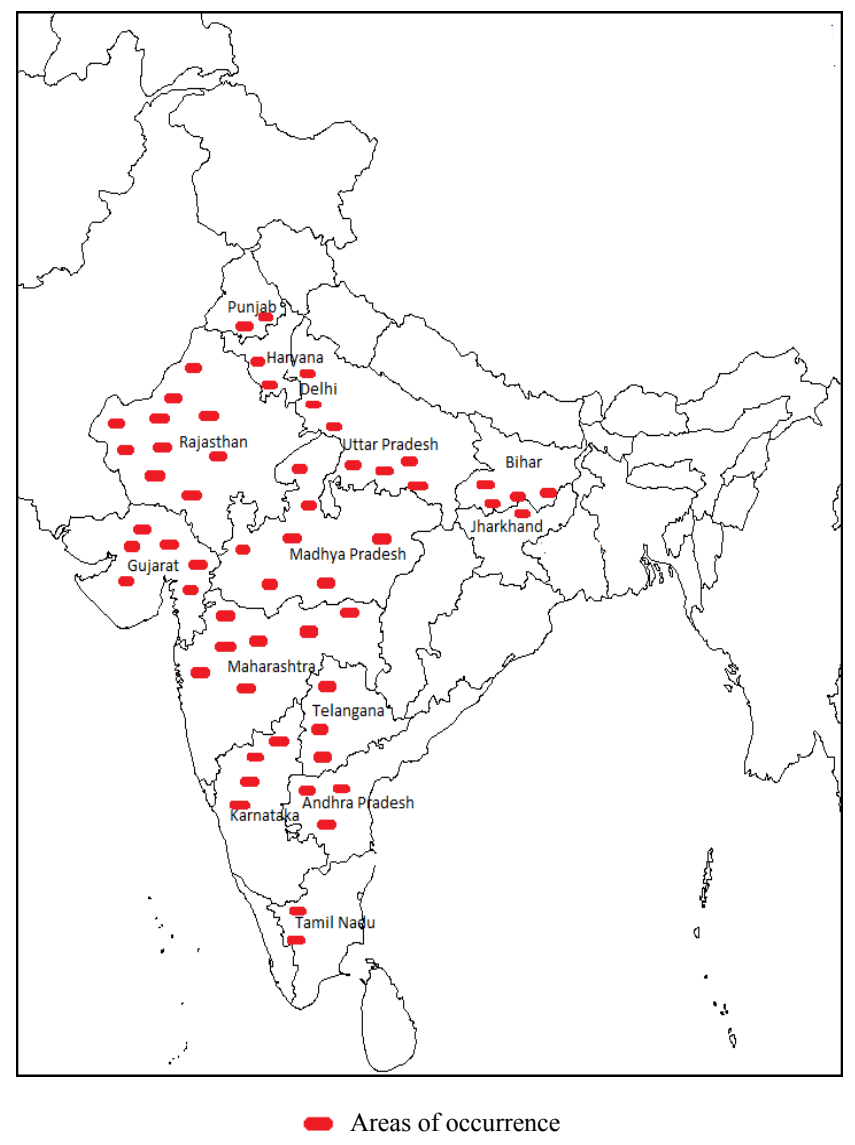

Figure 1. Map of India showing growth of Capparis decidua (Forssk.) Edgew.

\section{Commercial Use}

Capparis decidua (Forssk.) Edgew has been cultivated since past for several purposes. Different parts of caper plant are utilized in the form of drugs, foods and cosmetics $[16,17]$. The commercially significant parts of Capparis decidua (Forssk.) Edgew are the immature flower buds, which are used as food in the form of curry, pickled in vinegar or preserved in granular salt and as condiment mostly by the people living around the desert. Semi-mature fruits are called as caperberries and young shoots with small leaves pickled for use as a condiment. The flavor of caper can be considered as similar to mustard and black pepper. The strong aroma of caper comes from mustard oil: methyl isothiocyanate (released from glucocapparin molecules) arising from crushed plant tissues. Mature and semi-mature 
fruits are also eaten as a cooked vegetable after removal of bitterness and pungency by keeping in salt solution. Ashes obtained after incineration of caper roots may be utilized as a source of salt. In cultivating land this plant is grown to form hedges for protection [18]. Capparis decidua (Forssk.) Edgew. seeds are rich in oil, fibers and proteins. Seed oil contains prominent amount of oleic and linoleic acids. Hence, seeds can be used in various forms for food and feed [19]. Capparis is also used for landscaping, control of erosion and animal feeding [16, 17]. Capparis wood is moderately hard and heavy, resistant to termite attack [20] and is utilized for making tool handles, boat knees, burning fuel etc. [21]. In Rajput territory and Sudan, this plant is fed to camels and goats [22].

\section{Harvesting, Yield and Marketing Fruits}

Plants grown through seed start bearing fruits at 6 to 7 years of age, and vegetative propagated plants start fruiting after four years. The harvesting of the fruits is done manually. The thorns of the plant poses great difficulty for hand picking the fruits and natives collect the fruits by beating the crown with wooden sticks. The fruits are sold fresh in the local markets. The fresh fruits show astringency due to tannins and phenolic compounds. The astringency is removable by immersing fruits in a 5\% solution of common salt, or in butter milk, for 4-5 days in an earthen pot. After the removal of astringency, the green fruits can be made into a vegetable or they can be preserved by sun drying for use in the off season. The dried fruits, with 5-7\% moisture, can be preserved for 2-3 years in airtight containers and can be marketed later. Fruits can also be exported to foreign, urban and national markets. [23]

\section{Traditional \& Therapeutic Uses}

Capparis species have been utilized in medicine since ancient times. These plants were used first time about 2000 years BC by Sumerians [24, 25]. The roots, flowers, and fruits of these plants with potential medicinal benefits, have been in use since that time against infectious diseases without any side effects [26]. Sharma and Kumar (2008)[27] suggested that the biological effects of Capparis decidua (Forssk.) Edgew may be ascertain to presence of antimicrobial bioactive compounds, like phenolics, flavonoids, polyamine alkaloids, glucosinolates, and vitamins that decrease the growth of microorganism, and are negligibly harmful for their hosts. The medicinal use of Capparis decidua (Forssk.) Edgew is also mentioned in ancient books. By Kavirajas, the plant is regarded as acrid, laxative, counterirritant and stimulant. They often prescribe it in heart diseases, colic pains, scurvy and phthisis [22]. The plant act therapeutically in flatulence, anorexia, respiratory disorders, skin diseases, in general weakness and also act as anthelmintic and diuretic [28,29]. Infusion of Capparis decidua (Forssk.) Edgew is used externally for eruptions, boils, joint diseases and internally in cough and as an antidote in case of poisoning. Juice of fresh plant is used to kill worms in ear. It acts as a good substitute of senega [22, 30]. Crushed bark is applied as poultice for treatment of wounds [31]. Roots are acts as sudorific, thermogenic, expectorant, carminative, digestive, stimulant, antibacterial, aphrodisiac, anodyne, anthelmintic and useful in arthritis, dyspepsia, constipation, lumbago, odontalgia, amenorrhoea and dysmenorrhoea [32]. Root bark is known to be astringent, alterative, acrid, diaphoretic, alexeteric. Powder or infusion of root bark is used in gout, rheumatism, cough, dropsy, palsy, asthma, intestinal worms and intermittent fever. The root powder is applied externally on malignant ulcer [33]. Coal paste obtained after burning the wood is applied to muscular injuries [34]. Fresh leaves and young shoots, when chewed, relieves toothache immediately [35]. The local people of India and Pakistan consider caper fruits having anti-diabetic, eye smoothing, and laxative properties so, they use caper fruits in pickles and curry $[22,28,31,36]$. Hakeems in India, suggest using Caper fruit powder mixed with sugar ameliorate rheumatism and diarrhea in livestock animals. Plants of genus Capparis contain spermidine, glucosinolate, alkaloids, phenols, glycosides, and flavonoids, which have various pharmacological properties [37-41] and anti-inflammatory activities [42]. Polyamine alkaloid called as spermidine, reported in caper species, delays aging in yeast, flies, worms, and human immune cells through the induction of autophagy [43]. Pichiah et al. (2011) [44] suggested that spermidine is used for treating type 2 diabetes. Isocodonocarpine, isolated firstly from Capparis decidua (Forssk.) Edgew, found useful against inflammation and asthma [36]. $\beta$-Sitosterol showed a significant anti-inflammatory activity, similar to indomethacin, in carageenan-induced rat paw edema. $\beta$-sitosterol showed to inhibit ear inflammation induced by multiple applications of tetradecanoylphorbol-13-acetate in mice. It also inhibited adjuvant-induced rat paw edema by inhibition of cyclooxygenase and 5-lipoxygenase pathways [45]. Phenols, flavonoids, and indoles are reported as bioactive constituents with anti-inflammatory effects in many other plants [46, 47]. Compounds extracted from Capparis species have also shown to be useful for controlling the metabolism of lipids. Alcoholic extracts of bark, flowers, and roots of Capparis decidua (Forssk.) Edgew reduced cholesterol, triglycerides, LDL (low-density lipoproteins), and VLDL (very low-density lipoproteins) levels [48], whereas, Capparis decidua (Forssk.) Edgew fruit extract showed beneficial effect on blood sugar levels, glycated hemoglobin levels, and lipid profiles in diabetic and normal male rats. Rahmani et al. (2013) [49] study concluded that consumption of Capparis decidua (Forssk.) Edgew fruits might decrease levels of sugar in blood and improve lipid 
profile. Various uses of Capparis decidua (Forssk.) Edgew. are shown in Table 1.

\section{Nutritional Value}

Plants with adequate amount of protein, fiber, and essential minerals are valued for livestock and human nutrition [57-60]. Capparis species contains minerals in floral buds and fruits, which are used as vegetable and is pickled. The buds and fruit are also rich in protein, carbohydrates, lipids, and vitamins [55]. Capparis decidua (Forssk.) Edgew. is reported to have higher potassium content than several other nutritious trees. Kumar et al. (2013)[61] reported the presence of $\mathrm{P}(219.05 \mathrm{mg} 100 \mathrm{~g}-1)$, $\mathrm{Mg}$ (49.16 mg $100 \mathrm{~g}-1)$, Fe (4.64 mg $100 \mathrm{~g}-1), \mathrm{Zn}(0.31 \mathrm{mg}$ $100 \mathrm{~g}-1), \mathrm{Cu}(1.94 \mathrm{mg} 100 \mathrm{~g}-1), \mathrm{Na}(160.64 \mathrm{mg} 100$ g-1),proline (11.76 mg $100 \mathrm{~g}-1)$, Ca (3.24\%), crude protein $(14.94 \%)$, total carbohydrates $(73.48 \%)$, soluble carbohydrates $(18.03 \%)$, $\operatorname{starch}(15.28 \%)$, crude fiber (10.94\%), neutral detergent fiber (30.48\%),hemicelluloses $(11.45 \%)$, cellulose $(8.91 \%)$, lignin $(7.62 \%)$, crude fat $(5.38 \%)$ and total ash (5.97\%) in Capparis decidua (Forssk.) Edgew. fruits. Arginine is involved in rapid regeneration of adenosine triphosphate, cell proliferation, vasodilatation, neurotransmission, calcium release, and imparting immunity [62]. Capparis decidua (Forssk.) Edgew. berries acts as a good source of arginine. The Capparis decidua (Forssk.) Edgew. seed oil contains oleic acid, linoleic acid and palmitic acid in increasing order. So Capparis decidua (Forssk.) Edgew seed oil is a healthy source of fatty acids and thus, can be used in diet. The mature fruits, young shoots with small leaves and immature fruits are pickled in vinegar or granular salt. The presence of reducing sugar, fats, vitamin $\mathrm{C}$, antioxidants, alkaloids, and carotene makes it a dietary supplement [63]. Capparis decidua (Forssk.) Edgew. bud and ripened fruits extract are also used in the food processing industry as a flavor agent. [64]

\section{Chemical Constituents}

Isocodonocarpine (A), Spermidine alkaloid (B), Capparisinine (C), Capparidisine (D), Capparine, and capparinine have been isolated from Caper roots $[48,56]$. Codonocarpine (E), capparisine (F), cadabacine-26-O-d-glucoside, and capparipine-26-O-d-gluc oside have also been isolated from dry root bark of Capparis decidua (Forssk.) Edgew. plant [7, 48, 56, 65, 66,67]. N-acetylated spermidine alkaloids- 15-N-acetyl capparisine $(\mathrm{G})$, and 14-N-acetyl isocodonocarpine $(\mathrm{H})$ obtained from the root bark of Capparis decidua (Forssk.)
Edgew.. It can be considered that roots of Capparis species are rich in spermidine alkaloid compounds [54] and can be used as a natural source for isolation of these polyamine alkaloids for formation of phytomedicines. Spermidine and spermine polyamines exhibit antioxidant and anti-allergenic activities, and suppression on glycation process. Spermidine is a class of multifunctional polyamines, found in some animals and microorganisms. Spermidine and spermine polyamines are essential in the proliferation, growth, and development of mammalian cells. These polyamines exhibit antioxidant and anti-allergenic activities, and suppression on glycation process [68, 69]. Polyamines prevent arteriosclerosis and promote healthy hair growth attributed to their anti-inflammatory properties and cell proliferative properties [70-73]. $\beta$-Sitosterol (I), is a principal phytosterol present in several plant including Capparis decidua (Forssk.) Edgew has partial antimicrobial effect through inhibition of cyclooxygenase and 5-lipoxygenasepathways. Flavonoids are known to be the most abundant plant compounds in human diet. Flavonoids are commonly found in cell vacuoles of the outer coloring parts of the flowers, fruits, and leaves [74] and show anti-stress effects in plants. Seemingly, the concentrations of phenolics and flavonoids vary depending on the extraction methods, genetic factors, and climatic/growing conditions of different sites [75, 76]. Baghiani et al. (2012) [77] reported that ethyl acetate extracts of Capparis decidua (Forssk.) Edgew. leaves showed higher amounts of phenolic compounds and flavonoids, followed by the chloroform extracts of roots. Mann et al. (2013) [78] also investigated that the content of different compounds in extracts of Capparis decidua (Forssk.) Edgew, alters depending on the solvent used. Capparis decidua (Forssk.) Edgew. fruits also contain carotene, ascorbic acid, phytic acid and oxalic acid.

According to previous studies, water extract from roots of Capparis species exhibited better purgative effect as compared to alcoholic extracts indicating that different extracts can exhibit different pharmacological potential [79, 80]. Oil extract from leaves of Capparis decidua (Forssk.) Edgew. contains phenyl propanoid, terpenoids, isothiocyanate, and n-alkalenes [81]. Recently, isothiocyanates have shown as anti-cancer agents $[82,83]$. In another investigation, the oil extract of Capparis decidua (Forssk.) Edgew. showed presence of thymol, isopropyl isothiocyanate, butyl isothiocyanate, and 2-hexenol. Gupta and Ali [84] explored oxygenated heterocyclic constituents from the alcoholic extract of root-bark of Capparis decidua (Forssk.) Edgew. Quaternary ammonium compounds and alkaloids were isolated from Capparis decidua (Forssk.) Edgew leaves [85, 86]. (Figure 2) (Table 2) 
Table 1. Representation of traditional and therapeutic uses of various plant parts of Capparis decidua (Forssk.) Edgew. in treating different body ailments.

\begin{tabular}{|c|c|c|}
\hline Plant parts & Ailments & References \\
\hline Roots and root barks & $\begin{array}{l}\text { Digestive diseases, stimulant, anodyne, sudorific,constipation, Gout, cough, flu, } \\
\text { dropsy, palsy, asthma, and intestinal worms, lumbago, odontalgia, and } \\
\text { amenorrehoea, intermittemt fever, arthritis, thermogeic, expectorant, carminative, } \\
\text { aphrodisiac, anthelmintic, dyspepsia, astringent, diaphoretic, alexeteric }\end{array}$ & {$[32,50,51]$} \\
\hline $\begin{array}{l}\text { Leaves and young } \\
\text { shoots }\end{array}$ & Toothache, swellings, and blisters, Hypercholesterolemia & {$[28,52]$} \\
\hline Stem barks & $\begin{array}{l}\text { Toothache, cough, asthma, intermittent fever, rheumatism, inflammation, kidney } \\
\text { infection, and treatment of wounds as poultice }\end{array}$ & {$[31,53-55]$} \\
\hline Fruits and flowers & $\begin{array}{c}\text { Diabetes, respiratory diseases, skin, anthelmintic, diuretic, cardiac and } \\
\text { biliousness diseases, anti-diabetic and eyesight smoothing properties, laxative } \\
\text { potential, atherosclerosis, and plaque }\end{array}$ & {$[22,27,28,31,36,50,56]$} \\
\hline
\end{tabular}<smiles></smiles>

(A) Isocodonocarpine<smiles>NCCCCNCCCCN</smiles>

(B) Spermidine alkaloid<smiles></smiles>

(C) Capparisinine 


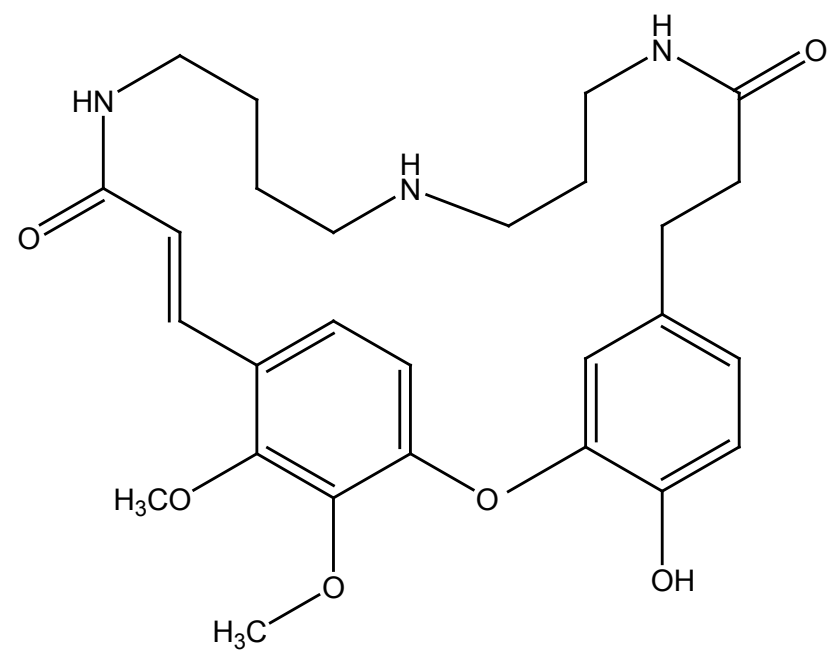

(D) Capparidisine<smiles>COc1cc(/C=C2/C(=O)NCCC2CNCC2CNC(=O)C=C2c2ccc(O)c(Oc3ccccc3)c2)ccc1O</smiles>

(E) Codonocarpine<smiles></smiles>

(F) Capparisine 
<smiles>COc1cc(/C=C/C(=O)NCCCCN(CC2CNC(=O)C=C2c2ccc(O)c(Oc3ccc(OC)c(OC)c3)c2)C(C)=O)ccc1O</smiles>

(G)15-N-acetyl capparisine<smiles>COc1cccc(/C=C/C(=O)NCCCN(CCCCNC(=O)/C=C/c2cccc(Oc3ccc(OC)c(OC)c3)c2)C(C)=O)c1</smiles>

(H) 14-N-acetylcodonocarpine<smiles>CCC(CCCC1CC[C@@H]2C1(C)CC[C@]1(C)C3(C)CCC(O)C=C3CCC21C)C(C)C</smiles>

(I) $\beta$-sitosterol 


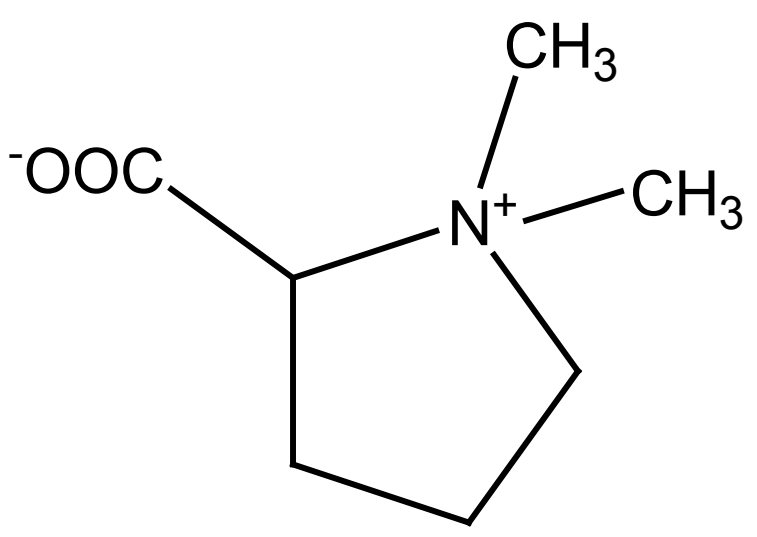

\section{(J) 1-Stachydrine}

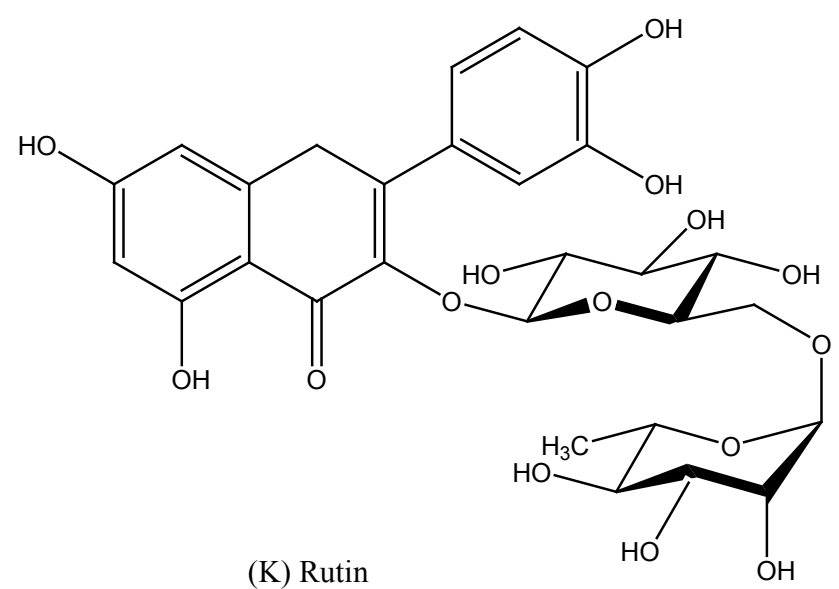<smiles></smiles>

(L) Kaempferol-7-rhamnoside

Figure 2. Structure of various chemical constituents of Capparis decidua (Forssk.) Edgew.(A to L) 
Table 2. Representation of chemical constituents found in various plant parts of Capparis decidua (Forssk.) Edgew.

\begin{tabular}{|c|c|c|}
\hline Plant Parts & Chemical constituents & References \\
\hline Fruits & $\begin{array}{l}\text { n-Triacontane, n-Pentacosane, } \beta \text {-Carotene, Carbohydrates, Proteins, Glucosinolates, } \\
\text { n-Triacontanol,Tetrahydropyran-2-one,2-Carboxy-1-dimethylpyrrolidine }\end{array}$ & {$[56,67]$} \\
\hline Flower & Nonacosane, $n$-Triacontane, $n$-Pentacosane, $n$-Triacontanol & {$[48,67]$} \\
\hline Flower buds & n-Triacontane, n-Pentacosane, Quercitin, Isodulcite, Nonacosane & {$[22,48,67]$} \\
\hline Shoots & $\begin{array}{l}\text { Thymol, Isopropyl isothiocyanate, } \\
\text { Butyl isothiocyanate, 2-Hexenol }\end{array}$ & [48] \\
\hline Leaves & $\begin{array}{l}\text { Phenyl propanoid, Terpenoids, Isothiocyanate, n-Alkalenes. Thomnocitrine, Kaempferol, } \\
\text { Quercetin, Isorhamnetin, rhamnocitrin, rhamnetin, rhamnazin, quaternary ammonium } \\
\text { compounds, alkaloids }\end{array}$ & {$[81,83,85-88]$} \\
\hline Roots & $\begin{array}{l}\text { Sitosterol, Spermidine alkaloid, Isocodonocarpine, Capparine, Capparinine, Cappariline, } \\
\text { Codonocarpine }\end{array}$ & {$[7,13,56,48]$} \\
\hline Root barks & $\begin{array}{c}\text { Cadabacine-26-O- } \beta \text {-d-glucoside, Isocodonocarpine, Capparine, Capparisine, } \\
\text { Codonocarpine, Capparispine-26-O--d-glucoside } \\
\text { Capparinine, N-acetylated spermidine } \\
\text { 14-N-acetyl isocodonocarpine, } \\
\text { 15-N-acetylcapparisine, Rutin(K), I-Stachydrine }(\mathrm{J}), \beta-\text { Sitosterol, Terpenoids, } \\
\text { Capparisesterpenolide }\end{array}$ & {$[7,48,54,65,66]$} \\
\hline Seeds \& Seed oil & $\begin{array}{l}\text { Glucocapparin, n-Pentacosane, n-Triacontanol, } \beta \text {-Sitosterol, Capric acid, Monoterpenes, } \\
\text { Sesquiterpenes, Tocopherols (Vitamin E) }\end{array}$ & {$[25,27,67,89]$} \\
\hline
\end{tabular}

Table 3. Representation of pharmacological activities shown by various plant parts of Capparis decidua (Forssk.) Edgew. and phytoconstituents responsible for pharmacological activity

\begin{tabular}{|c|c|c|c|}
\hline Plant parts & Pharmacological activity & Phytoconstituents & References \\
\hline $\begin{array}{c}\text { Capparis decidua } \\
\text { (Forssk.) Edgew. stems and } \\
\text { flowers }\end{array}$ & $\begin{array}{l}\text { Antibacterial, antifungal, } \\
\text { antiparasital activity }\end{array}$ & $\begin{array}{l}\text { Quarternary ammonium } \\
\text { compounds, Glucosinolate }\end{array}$ & {$[90,91]$} \\
\hline $\begin{array}{c}\text { Capparis decidua } \\
\text { (Forssk.) Edgew. root, stem, } \\
\text { fruit }\end{array}$ & $\begin{array}{l}\text { Antimicrobial activity, antifungal } \\
\text { activity }\end{array}$ & $\begin{array}{l}\text { Phenolic and flavanoid } \\
\text { compounds }\end{array}$ & {$[27,92]$} \\
\hline $\begin{array}{c}\text { Capparis decidua } \\
\text { (Forssk.) Edgew. seeds }\end{array}$ & Antimicrobial activity & Isothiocyanate aglycon & {$[13,93,94]$} \\
\hline $\begin{array}{c}\text { Capparis decidua } \\
\text { (Forssk.) Edgew. leaves }\end{array}$ & Antioxidant activity & $\begin{array}{c}\text { Phenolic compounds, } \\
\text { Polyphenols, Tocopherols, } \\
\text { Carotenoids }\end{array}$ & {$[95-97]$} \\
\hline $\begin{array}{c}\text { Capparis decidua } \\
\text { (Forssk.) Edgew. leaves }\end{array}$ & Antiplaque activity & Volatile oil-Thymol & {$[56,98]$} \\
\hline $\begin{array}{c}\text { Capparis decidua } \\
\text { (Forssk.) Edgew. stem }\end{array}$ & Hepatoprotective activity & $\begin{array}{c}\text { Flavonoids, Cyanogenic } \\
\text { glycosides, Triterpenes, Vit. C }\end{array}$ & [99] \\
\hline $\begin{array}{c}\text { Capparis decidua } \\
\text { (Forssk.) Edgew.. root bark }\end{array}$ & Anthelmintic activity & Spermidine alkaloids, Tannins & {$[54,100,101]$} \\
\hline $\begin{array}{c}\text { Capparis decidua } \\
\text { (Forssk.) Edgew. powdered } \\
\text { fruit }\end{array}$ & Antidiabetic activity & Alkaloids & {$[36,102]$} \\
\hline $\begin{array}{c}\text { Capparis decidua } \\
\text { (Forssk.) Edgew.. Fruit and } \\
\text { shoot }\end{array}$ & Antisclerotic activity & $\begin{array}{l}\text { Vitamins, Alkaloids, Phenolic } \\
\text { compounds }\end{array}$ & {$[52,103-106]$} \\
\hline $\begin{array}{l}\text { Capparis decidua } \\
\text { (Forssk.) Edgew. fruit, } \\
\text { flower, bark }\end{array}$ & Antihyperlipidemic activity & Saponins, Tannins & [52] \\
\hline $\begin{array}{c}\text { Capparis decidua } \\
\text { (Forssk.) Edgew. plant }\end{array}$ & Antisebum activity & $\begin{array}{l}\beta \text {-sitosterol, Essential fatty } \\
\text { acids,Thioglu-cosides }\end{array}$ & [107] \\
\hline $\begin{array}{c}\text { Capparis decidua } \\
\text { (Forssk.) Edgew. flowers, } \\
\text { stem }\end{array}$ & Sedative and anticonvulsant activity & Alkaloids & [108] \\
\hline $\begin{array}{c}\text { Capparis decidua } \\
\text { (Forssk.) Edgew. stem }\end{array}$ & $\begin{array}{l}\text { Analgesic and antinociceptive } \\
\text { activity }\end{array}$ & $\begin{array}{l}\text { Tannins, Diterpenes, Triterpenes, } \\
\text { steroids }\end{array}$ & [109] \\
\hline $\begin{array}{l}\text { Capparis decidua } \\
\text { (Forssk.) Edgew. stem, root, } \\
\text { root bark }\end{array}$ & Antiinflammatory activity & Isocodonocarpine, $\beta$-sitosterol & {$[36,45]$} \\
\hline $\begin{array}{l}\text { Capparis decidua } \\
\text { (Forssk.) Edgew. stem, } \\
\text { flower }\end{array}$ & Anti-termite activity & $\begin{array}{c}\text { Heneicosylhexadecanoate, } \\
\text { triacontanol, 2-carboxy-1, } \\
\text { 1-dimethylpyrrolidine, } \\
\text { 6-(1-hydroxy-non-3-enyl)-tetrahydr } \\
\text { opyran-2-one }\end{array}$ & [110] \\
\hline
\end{tabular}




\section{Pharmacological Activities}

Pharmacological activities of various parts of Capparis decidua (Forssk.) Edgew. have been shown in Table 3.

\section{Conclusions}

Capparis decidua (Forssk.) Edgew. has been used as an ethnic medicine in different parts of the world. Several researchers keenly participated and explored this plant for identifying, isolating, and extracting potential medicinal constituents which proved various pharmacological activities. Many of pharmacological activities have already been mentioned in text above but still a lot of focus needs to be addressed regarding this plant by scientists, chemists, pharmacists, microbiologists, and nutritionists. Despite the multitude of pharmacological activities shown by this plant some activities like antirheumatic, aphrodisiac which are traditionally well known but has not been authenticated by any researcher yet. Moreover clinical studies have not been conducted so far to conform to the results of preclinical studies.

\section{Acknowledgements}

We are very grateful to Prof. Kailash Agrawal \&Dr. R. D Agarwal of Department of Botany, University of Rajasthan for their appropriate and constructive suggestions.

\section{Conflict of Interest}

Authors declare that there are no conflicts of interest.

\section{REFERENCES}

[1] Anwar F, Latif S, Ashraf M, Gilani AH. Moringa oleifera Lam.: a food plant with multiple medicinal uses. Phytother. Res. 2007; 21: 17-25.

[2] Zaini NAM, Anwar F, Hamid AA, Saari N. Kundur [Benincasa hispida (Thunb.) Cogn.]: a potential source for valuable nutrients and functional foods. Food Res. Int. 2011; 44: $2368-2376$.

[3] Ghanbari R, Anwar F, Alkharfy KM, Gilani AH, Saari N. Valuable nutrients and functional bioactives in different parts of olive (Olea europaea L.) - a review. Int. J. Mol. Sci. 2012; 13: 3291-3340.

[4] Sahib NG, Anwar F, Gilani AH, Hamid AA, Saari N, Alkharfy KM. Coriander (Coriandrum sativum L.): a potential source of high-value components for functional foods and nutraceuticals - a review. Phytother. Res. 2013; 27: $1439-1456$

[5] WHO, 2002. WHO traditional medicine strategy, 2002-2005,
Geneva.

[6] Heywood, V. H., Capparaceae. In: Heywood VH (ed) Flowering plants of the world. Oxford University Press, Oxford; 1978, pp 119.

[7] Ahmad VU, Ismail N, Amber AUR. Isocodonocarpine from Capparis decidua (Forssk.) Edgew. Phytochemistry.1989; 28: 2493-2495.

[8] Metcalfe CR, Chalk L. Anatomy of The Dicotyledon (Leaves, stem and wood in relation to taxonomy with notes in economic uses), Vol. I, Oxford, At the Clarendon Press. 1950, $1 . v i$ and 1 vii.

[9] Kirtikar KR, Basu BD. Indian Medicinal Plants, 2nd edition, Delhi, India, 1933.

[10] Joseph B, Jini D. A medicinal potency of Capparis decidua (Forssk.) Edgew - a harsh terrain plant. Res. J. Phytochem. 2011; 5: 1-13.

[11] Singh D, Singh RK. Kair (Capparis decidua (Forssk.) Edgew): a potential ethnobotanical weather predictor and livelihood security shrub of the arid zone of Rajasthan and Gujrat. Indian J Trad Knowl 2011; 10:146-65.

[12] Pareek OP. Horticultural development in arid regions. Indian Horticulture. 1978; 23(2): 25-30.

[13] Muthana KD. Capparis decidua (Forssk.) Edgew. In Drake Hocking (ed.) Trees for dry and. Oxford and IBH publishing Co. Pvt. Ltd, New Delhi, Calcutta, Bombay, 1993, pp. 141-143.

[14] Samir MS, Marwat KH, Khattack JK. Studies on some halophytes of Peshawar district. Pakistan Journal of Science. 1986; 38(14): 39-42.

[15] Paul MS, Sen DN. A new report on dimorphism in seeds of Capparis decidua (Forssk.) Edgew. Indian desert. Current Science. 1987; 56(19): 1017-1018.

[16] Ozcan M. Ham vesalamurakapari (Capparis spp.) meyvelerininfiziksel, kimyasal o* zellikleriveyag asitleribiles-imi. [The physical and chemical properties and fatty acid compositions of raw and brined Caperberries (Capparis decidua (Forssk.) Edgew spp.)]. Tr. Journal of Agriculture and Forestry. 1998; 23(3): 771-776.

[17] Baytop T. Therapy with Medicinal Plants (Past and Present). Istanbul Universty Publications, Istanbul, Turkey, 1999.

[18] Hammer K. In: Hanelt P, Institute of Plant Genetics and Crop Plant Research (eds), 2001;1406-1412.

[19] Akgu“1 A, O” zcan M. Some compositional characteristics of capers (Capparis decidua (Forssk.) Edgew.) seed and oil. Grasas y Aceites 50(1), 49-52.

[20] Anonymous. Wealth of India. Raw materials vol. 2: CSIR, New Delhi, 1950, pp. 67.

[21] Singh U, Wadhawani AM, Joshi HM. A Dictionary of' Economic Plants in India. ICAR. New Delhi, 1983.

[22] Nadkarni KM, Nadkarni A. Indian Materia Medica: With Ayurvedic, Unani-tibbi, Siddha, Allopathic, Homeopathic Naturopathic \& Home Remedies, 3rd Ed. Popular Book Depot.

[23] Chavan AR, Oza GM. The Flora of Pavagadh (Gujarat State India). The Flora of Pavagadh, Gujarat State, India, 1966. 
[24] Aghel N, Rashidi I, Mombeini A. Hepatoprotective activity of Capparis spinosa L .root bark against $\mathrm{CCl} 4$ induced hepatic damage in mice. Iran J Pharm Res 2010; 6:285-90.

[25] Romeo V, Ziino M, Giuffrida D, Condurso C, Verzera A. Flavour profile of Capers (Capparis spinosa L.) from the Eolian Archipelago by HS-SPME/GC-MS. Food Chem 2007;101:1272-1278.

[26] Iwu M, Duncan AR, Okunji CO. In: Alexandria, V.A., Janick, J. (Eds.), New Antimicrobials of Plant Origin, Perspectives on New Crops and New Uses. ASHS Press, Alexandria, VA, 1999, pp. 457-462.

[27] Sharma B, Kumar P. Extraction and pharmacological evaluation of some extracts of Tridax procumbens and Capparis decidua. Int J Appl Res Nat Prod 2008;1:5-12.

[28] Vaidya BG, DravyagunaShastra. 2nd Ed., University Granthnirman Board, Gujarat State, 1995, 454.

[29] Sharma PV. Dravyaguna Vijnana. Vol. II, Vegetable drugs, Chaukhambha Bharti Academy, Varanasi, 2005;530-531.

[30] Shastri, G.M., Bhavprakash. Part-I, 1st Ed., Sastu Sahitya Vardhak karyalaya, Mumbai, 1957, 368.

[31] Marwat SK, Fazal UR, Usman K, Khakwani AA, Ghulam S, Anwar N, Sadiq M, Khan SJ. Medico-Ethnobotanical Studies of Edible Wild Fruit Plant Species from the Flora of North Western Pakistan, D.I. Khan District. J Med Pl Res 2011;5(16):3679-86

[32] Longman Orient., \& Vaidyaratnam, P.S., Varier's Indian Medicinal Plants, a compendium of 500 species. Vol 1, Arya Vaidya Shala, Kottakkal, 1994. 368.

[33] Chunekar, K.C. \& Pandey, G.S., Bhavprakash nighantu. Chaukhambha Bharti Academy, 8th Ed., Gokulbhavan, Varanasi, 1999, p. 546.

[34] Gupta AK, Sharma M. Reviews on Indian Medicinal Plants, Vol. 5 (Ca-Ce), Medicinal Plant Unit, ICMR, New Delhi, 2007,389

[35] Shastri, D., Aryabhishek. 11th Ed., Sastu Sahitya Vardhak Karyalaya, 1951, 176.

[36] Yadav P, Sarkar S, Bhatnagar D. Lipid peroxidation and antioxidant enzymes in erythrocytes and tissues in aged diabetic rats. Indian J. Exp. Biol.1997; 35: 389-392.

[37] Ghule B, Murugananthan G, Nakhat P, Yeole P. Immunostimulant effects of Capparis zeylanica Linn. leaves. J Ethnopharmacol 2006; 108:311-5.

[38] Tlili N, Elfalleh W, Saadaoui E, Khaldi A, Triki S, Nasri N. The Caper (Capparis L.): ethnopharmacology, phytochemical and pharmacologicalproperties. Fitoteraphy 2011a;82:93-101.

[39] Tlili N, Nasri N, Khaldi A, Triki S, Munné-Bosch S. Phenolic compounds, tocopherols, carotenoids and vitamin C of commercial Caper. J Food Biochem 2011b; 35:472-83.

[40] Yang T, Wang C, Liu H, Chou G, Cheng X, Wang Z. A new antioxidant compound from Capparis spinosa L. Pharm Biol 2010; 48:589-94.

[41] Yang Y, Han C, Liu Q, Lin B, Wang J. Effect of drought and low light on growth and enzymatic antioxidant system of Picea asperata seedlings. Acta Physiol Plant 2008; 30: 433-40.

[42] Mills S, Bone K. Principles and Practice of Phytotherapy. Modern Herbal Medicine. Churchill Livingstone, London, UK, 2000.

[43] Eisenberg T, Knauer H, Schauer A, Büttner S, Ruckenstuhl C, Carmona-Gutierrez D, Ring J, Schroeder S, Magnes C, Antonacci L. Induction of autophagy by spermidine promotes longevity. Nat Cell Biol 2009; 11:1305-14.

[44] Pichiah TPB, Suriyakalaa U, Kamalakkannan S, Kokilavani P, Kalaiselvi S, Sankar Ganesh D, Gowri J, Archunan G, Cha YS, Achiraman S. Spermidine may decrease ER stress in pancreatic beta cells and may reduce apoptosis via activating AMPK dependent autophagy pathway. Med Hypoth 2011; 77:677-9.

[45] Perianayagam J, Sharma S, Pillai K, Govil J, Singh V. In: Govil, J., Singh, V.(Eds.), Anti-Inflammatory Potential of beta-sitosterol on Acute and Chronic Inflammation Models. Phytopharmacology and Therapeutic Values 2008;4:25-35.

[46] Fu XP, Wu T, Abdurahim M, Su Z, Hou XL, Aisa HA, Wu H. New spermidine alkaloids from Capparis spinosa $\mathrm{L}$. roots. Phytochem Lett 2008;1:59-62.

[47] Matthäus B, Özcan M. Glucosinolates and fatty acid, sterol, and tocopherol composition of seed oils from Capparis spinosa L. and Capparis ovatea Desf. var. canescens (Coss.) Heywood. J Agric Food Chem 2005; 53:7136-41.

[48] Chahlia N. Effect of Capparis decidua (Forssk.) Edgew on hypolipidemic activity in rats. $\mathrm{J}$ Med Plant Res 2009;3:481-4.

[49] Rahmani R, Mehdi M, Mehrnaz K, Fateme H, Rahim H, Mohamadhosein S, Aliakbar Y. Effect of Capparis spinosa L. fruit hydroalcoholic extract on blood sugar and lipids in diabetic and normal rats. Zahedan J Res Med Sci 2013; $15: 34$.

[50] Warrier PK, Nambiar V, Ramankutty C. Indian medicinal plants: a compendium of 500 species. Orient Blackswan, 1996.

[51] Pandey G, Chunekar K, BhavprakashNighantu B, Chaukhambha Bharati Academy: Varanasi, 8th Ed. Gokulbhavan, Varanasi, 1998, India.

[52] Goyal R, Grewal R. The influence of teent (Capparis decidua (Forssk.) Edgew.) on human plasma triglycerides, total lipids and phospholipids. Nutr. Health. 2003; 17: 71-76.

[53] Afsharypuor S, Jeiran K, Jazy AA. First investigation of the flavour profiles of the leaf: ripe fruit and root of Capparis spinosa var. mucronifolia from Iran.Pharm. ActaHelv. 1998; 72: 307-309.

[54] Ahmad VU, Ismail N, Arif S, Amber AUR. Two new $\mathrm{N}$-acetylated spermidine alkaloids from Capparis decidua (Forssk.) Edgew. J. Nat. Prod. 55; 1992: 1509-1512.

[55] Özcan M. Mineral composition of different parts of Capparis ovata Desf. var.canescens (Coss.) Heywood growing wild in Turkey.J. Med. Food. 2005; 8: 405-407.

[56] Rathee S, Rathee P, Rathee D, Rathee D, Kumar V. Phytochemical and pharmacological potential of kair (Capparis decidua (Forssk.) Edgew). Int. J. Phytomed. 2011; 2: 10-17. 
[57] Ahmad K, Ashraf M, Khan ZI, Valeem EE. Evaluation of macromineral concentrations of forages in relation to ruminants' requirements: a case study in Soone Valley, Punjab, Pakistan. Pak. J. Bot. 2008; 40: 295-299.

[58] Ashraf M, Khan A, Azmi A. Cell membrane stability and its relation with some physiological processes in wheat. ActaAgronHungar. 1992; 41: 183.

[59] Irigoyen J, Einerich D, Sánchez D. Water stress induced changes in concentrations of proline and total soluble sugars in nodulated alfalfa (Medicago sativa) plants. Physiol. Plant. 1992; 84: 55-60.

[60] Paterson RT, Karanja GM, Nyaata OZ, Kariuki IW, Roothaert RL. A review of tree fodder production and utilization within small holder agroforestry systems in Kenya. Agrofor. Sys. 1998; 41: 181-199.

[61] Kumar S, Sharma R, Kumar V, Vyas GK, Rathore A. Combining molecular-marker and chemical analysis of Capparis decidua (Capparaceae) in the Thar Desert of Western Rajasthan (India). Rev. Biol. Trop. 2013; 61: 311-320.

[62] Nieves Jr C, Langkamp-Henken B. Arginine and immunity: a unique perspective. Biomed. Pharmacother. 2002; 56: 471-482.

[63] Mahasneh AM. Screening of some indigenous Qatari medicinal plants for antimicrobial activity. Phytother. Res. 2002; 16: 751-753.

[64] Angelini G, Vena GA, Filotico R, Foti C, Grandolfo M. Allergic contact dermatitis from Capparis spinosa L. applied as wet compresses. Contact Dermatitis. 1991; 24: 382-383.

[65] Ahmad VU, Arif S, Amber AR, Usmanghani K, Miana G. New spermidine alkaloid from Capparis decidua (Forssk.) Edgew. Heterocycles. 1985; 23: 3015-3020.

[66] Ahmad VU, Arif S, Amber AUR, Fizza K. Capparisinine, a new alkaloid from Capparis decidua (Forssk.) Edgew Liebigs Ann. Chem. 1987; 161-162.

[67] Mishra S, Tomar P, Lakra N. Medicinal and food value of Capparis decidua (Forssk.) Edgew - a harsh terrain plant. Indian J. Trad. Knowl. 2007; 6: 23.

[68] Fujisawa S, Kadoma Y. Kinetic evaluation of polyamines as radical scavengers. Anticancer Res. 2005; 25: 965-970.

[69] Soda K. Polyamine intake dietary pattern, and cardiovascular disease. Med.Hypotheses, 2010; 75: 299-301.

[70] de la Pena NC, Sosa-Melgarejo JA, Ramos RR, Méndez JD. Inhibition of platelet aggregation by putrescine, spermidine, and spermine in hypercholesterolemic rabbits. Arch Med Res 2014; 75:299-301.

[71] Gugliucci A, Menini T. The polyamines spermine and spermidine protect proteins from structural and functional damage by AGE precursors: a new role for old molecules? Life Sci 2003; 72:2603-16.

[72] Ramot Y, Pietilä M, Giuliani G, Rinaldi F, Alhonen L, Paus R. Polyamines and hair: a couple in search of perfection. Exp Dermatol 2010; 19:784-90.

[73] Ramot Y. Spermidine promotes human hair growth and is a novel modulator of human epithelial stem cell functions. PLoS One 2011; 6:1-11.
[74] Middleton JE. Effect of plant flavonoids on immune and inflammatory cell function. Adv Exp Med Biol 1998; 439:175-182.

[75] Hashempour A, Ghazvini RF, Bakhshi D, Sanam SA. Fatty acids composition and pigments changing of virgin olive oil (Olea europea L.) in five cultivars grown in Iran. Aust J Crop Sci 2010; 4:258.

[76] Islam MS, Yoshimoto M, Ishiguro K, Okuno S, Yamakawa O. Effect of artificial shading and temperature on radical scavenging activity and polyphenolic composition in sweetpotato (Ipomoea batatas L.) leaves. J Am Soc Hort Sci 2003; 128:182-187.

[77] Baghian, A, Ameni D, Boumerfeg S, Adjadj M, Djarmouni M, Charef N, Khennouf S, Arrar L. Studies of antioxidants and xanthine oxidase inhibitory potentials of root and aerial parts of medicinal plant Capparis spinosa L. Am J Med Med Sci 2012; 2: 25-32.

[78] Mann S, Chaudhary I, Gupta RK. Value addition scenario of arid foods of desert area and evaluation of their nutritional and phytochemical potential. Int J Pharm Life Sci 2013; 4:2335-39.

[79] Gaind K, Juneja T, Jain P. Anthelmintic and purgative activity of Capparis decidua (Forssk.) Edgew. Indian J Hosp Pharm 1969; 2:153-155.

[80] Hundiwale JC, Sonawane RS, Patil RN, Hatapakki BC. Evaluation of Capparis decidua for anthelmintic and antimicrobial activities. Indian J Nat Prod 2005;20:10-3.

[81] Ahmed Z, Rizk A, Hammouda F, Seif El-Nasr M. Glucosinolates of Egyptian Capparis species. Phytochemistry. 1972; 11: 251-256.

[82] Tesoriere L, Butera D, Gentile C, Livrea MA. Bioactive components of Caper (Capparis spinosa L.) from Sicily and antioxidant effects in a red meat simulated gastric digestion. J. Agric. Food Chem 2007:55:8465-71.

[83] Zhang Y. Cancer-preventive isothiocyanates: measurement of human exposure and mechanism of action. Int. J. Mol. Sci. 2004; 555: 173-190.

[84] Gupta J, Ali M. Oxygenated heterocyclic constituents from Capparis decidua root-barks. Indian $\mathrm{J}$ Heterocycl Chem 1997; 6:295-302.

[85] Delaveau P, Koudogbom B, Pousset JL, Alcaloïdes chez les capparidaceae. Phytochemistry. 1973; 12: 2893-2895.

[86] McLean WFH, Blunden G, Jewers K. Quaternary ammonium compounds in the Capparaceae. BiochemSyst Ecol. 1996; 24: 427-434.

[87] Pelotto JP, Del Pero Martinez MA. Flavonoid aglycones from Argentinian Capparis species (Capparaceae). BiochemSyst Ecol. 1998; 26: 577-580.

[88] Juan PP, Martinez MDP. Flavonoid aglycones from Argentinian Capparisspecies (Capparaceae). J. Biochem. Syst. Ecol. 1998; 26: 577-580.

[89] Arena A, Bisignano G, Pavone B, Tomaino A, Bonina F, Saija A, Cristani MD, Arrigo M, Trombetta D. Antiviral and immunomodulatory effect of a lyophilized extract of Capparis spinosa L. buds. Phytother. Res. 2008; 22: 313-317. 
[90] Upadhyay RK, Rohatgi L, Chaubey MK, Jain SC. Ovipositional responses of the pulse beetle, Bruchuschinesis (Coleopetra Bruchidae) to extracts and compounds of Capparis decidua (Forssk.) Edgew. J Agr Food Chem. 2006; 54: 9747-9451.

[91] Martınez-Carballo E, Sitka A, Gonzalez-Barreiro C, Kreuzinger N, Furhacker M, Scharf, S.Determination of selected quaternary ammonium compounds by liquid chromatography with mass spectrometry. Part I. Application to surface, waste and indirect discharge water samples in Austria. Environ Poll. 2007; 145: 489-496.

[92] Ravi KU, Shoeb A, Rajani T, Leena R, Subhash CJ. Screening of antimicrobial potential of extracts and pure compounds isolated from Capparis decidua. J. Med. Plants Res. 2010; 4: 439-445.

[93] Gaind K, Juneja T, Bhandarkar P. Volatile principle from seeds of Capparis decidua (Forssk.) Edgew. Kinetics of in vitro antibacterial activity against Vibrio choleraeogava, inaba, and eltor. Indian J. Pharm. 1972; 34: 86-88.

[94] Juneja T, Gaind K, Panesar A. Investigations on Capparis decidua; study of isothiocyanate glucoside. Panjab Univ. Res. Bull. 1971; 21: 519-521.

[95] Tepe B, Sokmen M, Akpulat HA, Sokmen A. Screening of the antioxidant potentials of six Salvia species from Turkey. Food Chem. 2006; 95: 200-204.

[96] Ihme N, Kiesewetter H, Jung F, Hoffman K, Birk A, Müller A. Grützner, K., Leg oedema protection from a buckwheat herb tea in patients with chronic venous insufficiency: a single-centre, randomised, double-blind, placebo-controlled clinical trial. Eur. J. Clin. Pharmacol. 1996; 50: 443-447.

[97] Sommer A, Davidson FR. Assessment and control of vitamin A deficiency: the annecy accords. J. Nutr. 2002; 132: 2845S-2850S.

[98] Upadhyay RK. Insecticidal Properties of Kareel Plant (Capparis decidua (Forssk.) Edgew: Capparidaceae) a Desert Shrub: A Review. World Journal of Zoology. 2013; 8(1): 75-93.

[99] Ali SA, Al-Amin TH, Mohamed AH, Gameel AA. Hepatoprotective activity of aqueous and methanolic extract of Capparis decidua stem against Carbon tetrachloride induced liver damage in rats. Journal of Pharmacology and Toxicology. 2009; 4 (4): 167-172.
[100] Dash G, Suresh P, Sahu S, Kar D, Ganapaty S, Panda S. Evaluation of Evolvulus alsinoides Linn. for anthelmintic and antimicrobial activities. J. Nat.Remedies. 2002; 2: 182-185.

[101] Shivkar Y, Kumar V. Anthelmintic activity of latex of Calotropis procera. Pharm. Biol. 2003; 41: 263-265.

[102] Sharma B, Salunke R, Balomajumber C, Daniel S, Roy P. Anti-diabetic potential of alkaloid rich fraction from Capparis decidua on diabetic mice. J Ethnopharmacol. 2010; 127(2): 457-462.

[103] Purohit A, Vyas KB. Hypolipidaemic efficacy of Capparis decidua fruit and shoot extracts in cholesterol fed rabbits. Indian J Exp Biol. 2005; 43(10): 863-866.

[104] Purohit A, Vyas KB. Effect of Capparis decidua plant extract in prevention of plaque formation in thoracic aorta of cholesterol fed rabbits. 76th Congress of the European Atherosclerosis Society; June 10-13, 2007, Helsinki, Finland. PO11-298.

[105] Koshy AS, Anila L, Vijayalakshmi NR. Flavonoids from Garcinia cambogia lower lipid levels in hypocholesterolemic rats. Food Chem. 2001; 72: 289-294.

[106] Anila L, Vijayalakshmi NR. Flavonoids from Embilica officinalis and Mangifera indica, effectiveness for dyslipidemia. J Ethnopharmacol. 2002; 79: 81-87.

[107] Zaman S, Akhtar N, Khan BA, Mahmood T, Rasul A, Mahmood A, Aamir MN, Ali A. Development of a sebum control cream from a local desert plant Capparis deciduas. Journal of Medicinal Plants Research. 2012; 6(5): 744-748.

[108] Goyal M, Nagori BP, Sasmal D. Sedative and anticonvulsant effects of an alcoholic extract of Capparis decidua. J Nat Med. 2009; 63: 375-379.

[109] Dev SK, Shukla A, Choudhury PK, Singh GK. Analgesic and anti-nociceptive activity of hydroethanolic extract of Capparis decidua (Forssk.) Edgew Linn. Asian Journal of Pharmacy and Pharmacology. 2015; 1(1): 40-44.

[110] Upadhyay RK, Jaiswal G, Ahmad S, Khanna L, Jain SC. Antitermite activities of Capparis decidua Extracts and Pure Compounds against Indian White Termite Odonto termesobesus (Isoptera: Odontotermitidae). Hindawi Publishing Corporation Psyche Volume 2012, Article ID 820245, 9 pages doi:10.1155/2012/820245. 